\title{
Foreign Precedents in Judicial Argument: A Theoretical ACCOUNT
}

\author{
Stefano Bertea and Claudio Sarra"
}

\begin{abstract}
:
Recourse to precedents in legal adjudication is a source of intriguing theoretical challenges and serious practical difficulties. That is especially so when we have to do not with domestic precedents but with foreign ones, that is, with decisions taken by foreign courts and international judicial institutions, particularly when there is no formal obligation for a court to resort to foreign law. Can a case decided by the judiciary of a different legal order - even if that case is remote and that legal order operates under different procedural rules and substantive laws - have any bearing on a dispute arising domestically here and now? Should such a foreign precedent be acknowledged to have any (formal) binding force on the case in question? How could the practice of following foreign precedents be justified? This paper is primarily meant to lay the theoretical basis on which those questions can be addressed. The basis on which we proceed in answering those questions essentially lies in a theory of legal reasoning that, for lack of a better phrase, can be labelled a dialectical approach informed by standards of discursive rationality.
\end{abstract}

\section{Keywords:}

Foreign precedent, Legal Reasoning, Jurisprudence, Dialectical Rationality, Legal Authority.

TABLE OF CONTENTS

I. INTRODUCTION ………....................................................................

II. Foreign Precedent In Legal Adjudication ......................................... I 4 /5

\footnotetext{
"We wish to express our indebtedness to Daniele Velo dal Brenta, Stefano Fuselli, Federico Reggio, Paolo Sommaggio, Sean Thomas, Filippo Valente, Francesca Zanuso, and the anonymous reviewers for this journal for reading and commenting on earlier drafts of this work. Needless to say, responsibility for the views expressed herein, as well as for any errors of form or content, rests solely with us. Finally, thanks are due to the University of Leicester that granted one of the authors one academic semester of study leave during which time the work towards the completion of this essay has been finalised. Stefano Bertea is Reader in Law, School of Law, University of Leicester; Claudio Sarra is Lecturer in Law, School of Law, University of Padua. While the authors discussed every single point of this work, paragraphs I, III, IV.r and V can be attributed to Stefano Bertea, and paragraphs II, IV and IV.2 to Claudio Sarra.
} 


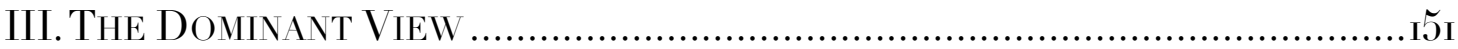

IV. An Alternative Perspective.............................................................

I. Dialectical Model for Legal Reasoning..........................................59

2. Dialectic and Reasoning with Foreign Precedent...........................167

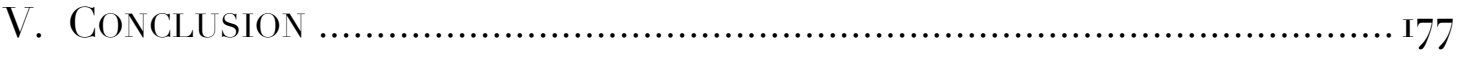

\section{INTRODUCTION}

Precedents matter in law. To be sure, not every legal order attaches the same weight and significance to precedent, but none of them treats it as entirely insignificant: it stands as a cornerstone of common law systems, for example, while enjoying informal recognition in civil law systems. Under the doctrine of precedent, decisions taken by courts of higher rank in the judicial hierarchy, as well as earlier decisions by the same court, must also apply to later cases that fall within the purview of the same decision. ${ }^{\prime}$ As much as the doctrine of precedent may be widely practiced and supported by a presumptively strong set of justificatory reasons, it has hardly commanded general acceptance. Recourse to precedents in legal adjudication is a source of intriguing theoretical challenges and serious practical difficulties. ${ }^{2}$ That is

' Precedents are traditionally said to have sertical effect when they bind lower courts and horizontal effect when they bind a court to its own earlier decisions (and the doctrine of precedent is correspondingly called vertical in the former case and horizontal in the latter). For an introduction to this distinction, see F Schauer, Thinking Like a Lawyer: A New Introduction to Legal Reasoning (Cambridge, Mass. Harvard University Press 2009), 36-7 and 4I-4.

${ }^{2}$ The doctrine of precedent has been a topic of extensive theoretical debate. Among the most significant contributions to this debate are A Goodhart, 'Determining the Ratio Decidendi of a Case' (1930) 40 Yale Law Journal ı6г; A Goodhart, 'The Ratio Decidendi of a Case'(1959) 22 Modern Law Review in7; R Summers, 'Two Types of Substantive Reasons: The Core of a Theory of Common-Law Justification' (1978) 63 Cornell Law Review 7o7; J Raz, The Authority of Law: Essays on Law and Morality (OUP I979), I80; N MacCormick, 'Why Cases Have Rationes and What These Are' in L Goldstein (ed), Precedent in Las, (Clarendon Press 1987), ı55; M Moore, 'Precedent, Induction, and Ethical Generalization', in L Goldstein (ed), Precedent in Law (Clarendon Press 1987), ı83; S Perry, 'Judicial Obligation, Precedent and the Common Law' (I987) 7 Oxford Journal of Legal Studies 2I5; F Schauer, 'Precedent' (1987) 39 Stanford Law Review 57ı; S Perry, 'Second-Order Reasons, Uncertainty and Legal Theory' (I989) 62 Southern California Law Review 913; L Alexander, 'Precedent' in D Patterson (ed), A Companion to the Philosophy of Law and Legal Theory, (Blackwell I996), ; B Levenbook, 'The Meaning of a Precedent' (2000) 6 Legal Theory i85; G Lamond, 'Do Precedents Create Rules?' (2005) I5 Legal Theory I; F Schauer, 'Authority and Authorities' (2008) 94 Virginia Law Review i93ı; and G Lamond, 'Persuasive Authority in the Law' (2010) XVII The Harvard Review of 
especially so when we have to do not with domestic precedents but with foreign ones, that is, with decisions taken by foreign courts and international judicial institutions, particularly when there is no formal obligation for a court to resort to foreign law. Can a case decided by the judiciary of a different legal order - even if that case is remote and that legal order operates under different procedural rules and substantive laws - have any bearing on a dispute arising domestically here and now? More to the point, should such a foreign precedent be acknowledged to have any (formal) binding force on the case in question? And how could the practice of following foreign precedents be justified? These are but a few of the main questions raised by appeal to precedents set in other jurisdictions.

Whereas answering these questions is not just of theoretical significance - especially today, issues concerning the use of foreign precedents in judicial decision-making are practically relevant, as international economic transactions and transnational social interactions are multiplying, and with them the potential for legal disputes involving actors from different legal orders - this paper is primary meant to lay the theoretical basis on which one can make sense of the use of foreign precedents in domestic adjudication. More specifically, the central question for us will be: What role, if any, should foreign precedents have in domestic adjudication? The basis on which we proceed in answering that question fundamentally lies in a theory of legal reasoning. We will be arguing, in other words, that in order to determine whether and why foreign precedents should be relied on, it is essential to have a correct grasp of the nature of reasoning in law. This is to say that we proceed from the premise that for an insightful account of the practice of recourse to foreign precedent in judicial decision-making, we will first need a theory of both law and reasoning.

For lack of a better phrase, the theoretical framework we set up in this essay will be labelled a dialectical approach informed by standards of discursive rationality. We call the approach 'dialectical' because it conceives of legal reasoning as an exchange of arguments concerning what given subjects ought to do in a specific context. The structure of legal reasoning will accordingly be understood as shaped by discussions between individuals who defend conflicting claims and 
argue against one another. This also means that legal reasoning is an essentially context-dependent activity: the specific forms taken by sound legal reasoning depend heavily on, and so are largely defined by, how actual interactions proceed among those who take part in the argumentative exchanges constitutive of legal reasoning in a courtroom, typically the judge, the prosecutor, and the parties to a dispute. ${ }^{3}$ Therefore, no adequate account of legal reasoning can be provided while neglecting the argumentative moves and strategies of actual discussants in a courtroom. But, on the other hand, the contextdependence is not radical, and so neither is the indeterminacy of the processes of reasoning in law. That is because sound legal reasoning unfolds in a space whose outlines are broadly framed in advance by a set of general rational standards which we call the principles of discursive rationality. These rational standards governing legal reasoning are so described - as principles of discursive rationality because their content is owed to the necessary presuppositions underpinning the communicative interactions between parties in a legal proceeding (which parties can for all practical purposes be equated with discussants, or participants in a discussion). So, as much as legal reasoning may be context-sensitive, its exercise in any specific instance and context will still be bound by general standards of reason. Hence the label we have chosen for our account as offering a dialectical approach to legal reasoning shaped by principles of discursive rationality.

This approach issues from two theoretical streams: on the one hand, we find the tradition emphasising the dialectical element of reasoning in law, on the other hand, there is the tradition conceiving practical reasoning as a discursive practice. Our study is, thus, meant to combine two existing traditions of legal thoughts that so far have

\footnotetext{
${ }^{3}$ Our stipulation in this essay is that the actors in courtroom proceedings are the judge, the prosecutor, and the parties. We are aware that the prosecutor's role is absent from a number of legal systems and types of legal proceeding. In addition, it may be that a mediator or arbitrator, replaces the judge in some proceedings. So, we ask the reader to bear in mind that our argument may need some adjustment when set in the context of legal orders and proceedings where some of the actors we mention are absent or are replaced by others. But we are inclined to believe that the required adjustments do not entail any revision of the main argument we offer or of the central claims we defend. Finally, by way of terminological clarification, by 'parties' we mean not only the actual persons asserting claims against each other in a dispute but also their counsel.
} 
largely proceeded independently from one another and yet, we think, can be made to work together towards a better understanding of legal adjudication. Whilst the theoretical framework we introduce builds on views that have already been championed by others, the combination of ideas offered here has not been discussed in any systematic way before. The originality of the argument is due to the (novel) effort to defend a view combining a universalist element - the claim that certain general, inescapable principles exist which govern any form of reasoning aimed at settling legal disputes - with a context-sensitive and, ultimately, particularistic dimension - the conceptual scheme that characterises dialectical approaches to practical reasoning. This makes our conception at once universalistic and particularistic: Kantian in the former sense, Aristotelian in the latter. For, on the one hand, we draw on the idea of necessary preconditions of deliberation, qua specific form of action, which is an idea central to Kant's practical philosophy; on the other hand, we look to dialectic, which is an idea that finds a most comprehensive and sophisticated treatment in Aristotle's body of work. This may give rise to the impression that we are looking at an impossible portmanteau theory seeking to bring together two irreconcilable stances (the universalistic and the particularistic), which are rooted in two traditions (the Kantian and the Aristotelian) conventionally regarded as incompatible. ${ }^{4}$ However, that is only an impression, because the two aspects of the theory the dialectic one and the discursively rational one) are welded by way of a unifying element through which we seek to explain legal reasoning as an activity based on discussion. This notion of discussion, as properly understood and carried out, provides us with a model that functions as both a heuristic device and a normative-practical tool enabling different parties to work out their controversies by reasoning about the issues in question. What this theoretical framework translates to is not an algorithm but a conceptual scheme within which to reason in law. So, while the framework itself is context-independent (it relies on constitutive principles that apply everywhere across the board for any kind of argumentative discussion), its use is going to be necessarily context-dependent, for there is no discussion that can take place in abstracto, independently of the interests, contents, and conceptions

\footnotetext{
${ }^{4}$ The otherwise widespread view that the Kantian tradition and the Aristotelian tradition of practical philosophy are incompatible, or even conflicting, has recently been challenged in C. Korsgaard, Self-Constitution (Oxford University Press 2009), I4 in a convincing way.
} 
that the parties bring to the table. It is in this way that dialectic, as an enabling framework for discussion, can secure the unity and coherence of a general theory of legal reasoning, a theory in light of which one can explain the nature of recourse to foreign precedent in domestic judicial adjudication, while laying out the conditions subject to which such recourse can be justified.

The argument we are making is organised as follows. We begin (in Section II) by introducing the current debate over the practice of relying on foreign precedent in legal adjudication. Then (in Section III) we show that the dominant view - which tends to consider that use questionable, permitting it only under strict conditions - implies a given conception of reasoning in law. We run through the theoretical assumptions underlying the dominant view and finally (in Section IV.) we introduce an alternative account - a dialectical approach to legal issues informed by the idea of discursive rationality. The account will be used to support the conclusion that there is nothing either puzzling or objectionable about the appeal to foreign precedents in law, provided that the foreign precedent a court plans to invoke in its decision is discussed and tested for relevance by the prosecutor and the parties through the adversarial procedures that frame a legal proceeding. The argument so laid out does not amount to a complete theory of foreign precedents to be sure, but it does at least offer a broad conceptual framework within which such a comprehensive theory can be worked out.

\section{Foreign Precedent In Legal AdJudication}

In several legal systems around the world recourse to foreign case law in domestic legal adjudication is both a recurrent occurrence and a novel development. ${ }^{5}$ For a long time, institutions entrusted with

\footnotetext{
${ }^{5}$ Countless cases are decided by appeal to foreign precedents in different areas of law. Worthy of mention among them are, in the United States: Nex York v. United States, 326 U.S. 572 (1946); Filartiga v. Pena-Irala, 63o F.2d 876 (2nd Cir. r98o); Kadic ง. Karadzic, 7o F.3d 232 (2nd Cir. 1995); Abebe-Jira ง. Negewo, 72 F.3d 844 (uth Cir. 1996); Printz ง. United States, 521 U.S. (1997); Washington v. Glucksberg, 521 U.S. 72I (1997); Knight •. Florida, 528 U.S. 990 (I999); and Lawrence •. Texas, 539 U.S. 558 (2003); in South Africa: State v. Makwayanyane, i995 (3) SALR 39i; State v. Zuma, I995 (2) SALR 642; Ferreira •. Levin, 1996 (I) SALR 984; Shabalala v. Attorney-General, Transvaal, 1996 (I) SALR 725; and State v. Coetzee, I997 (3) SALR 527; in Canada: Calder v. Attorney General of British Columbia [1973] S.C.R. 313 and Van der Peet $\bullet$. The
} 
adjudication in colonies have looked to the case law of the relative imperial states - and in particular to the case law of those countries' highest courts - especially in deciding disputes not covered by domestic statutes and precedents. Over time, this international judicial communication has progressively become bidirectional, so much so that today the courts in one country will find themselves at the same time drawing on the case law of those in another and seeing their own case law invoked by courts in countries elsewhere in the world. ${ }^{6}$ In addition, with the establishment of international institutions and transnational orders having their own adjudication systems (as in the case of the EU and the WTO), national courts have found themselves engaging in different ways and to different degrees with the jurisprudence (or case law) of the international courts attached to those institutions and orders. At the same time, international courts have reciprocated, at least occasionally, by taking national legal practices and case law into account in their own opinions.?

There is a quite important point that bears mentioning in regard to the role those courts play in the development of transnational orders. Sometimes a transnational court is created in order for a set of principles enshrined in a treaty to have concrete meaning and application, and yet no code or statute can be found that will fill up the space between the sweeping principled assertion (as in the European Convention on Human Rights) and its specific instantiations. What follows is a great deal of room for manoeuvre in determining whether something is prohibited under those principles. One can appreciate, then, how important it becomes, in this sort of situation, to be able to rely on a settled use of precedents, as well as on local judicial practice, in dealing with the adjudication of rights. And this also shows why it

Queen [1996] 2 S.C.R. 5o7; in the United Kingdom: Derbyshire County Council o Times Nexspapers Ltd. [1992] UKHL 6; and, in Italy: Corte di Cassazione, sent. 1/488/2004, and Corte di Cassazione, sent. 21748/2007.

${ }^{6}$ For a detailed introduction to this evolution in the use of foreign precedents around the world, see A Slaughter, 'A Global Community of Courts' (2003) 44 Harvard International Law Journal igi and G De Vergottini, Oltre il Dialogo tra le Corti: Giudici, Diritto Straniero, Comparazione (Il Mulino 20го). See also S Levinson, 'Looking Abroad When Interpreting the U.S. Constitution: Some Reflections' (2004) 39 Texas International Law Journal, 353; C G Nucera, 'L'Influence du Precedent Étranger sur le Juge National' (2009) i Diritto e Impresa/Europa 32.

7 Paradigmatic in this respect is the relationship that has gradually developed, over the course of several judgments, between the European Court of Justice and the constitutional courts of EU member states. 
makes sense for judicial decisions to travel across jurisdictions: supranational courts can draw on those local practices in backing up their own opinions, thus packaging together a more general and cohesive set of rules and principles that national courts can in turn invoke as binding. Foreign precedents have thus become the basis for a complex multi-directional development in the development of many legal systems.

As these preliminary remarks suggest, recourse to foreign jurisprudence is not a monolithic practice but rather an internally differentiated one. At one extreme we find courts simply pointing out a precedent from abroad, and they may even do so in generic terms. ${ }^{8} \mathrm{At}$ the other extreme, we find courts genuinely engaging with foreign jurisprudence. This engagement may in turn take different forms: it may consist in a court drawing on precedents from other legal systems without interacting with their judiciary on the merits of the decisions, or it may consist in an actual 'dialogue', where courts in different countries governed by different legal systems consciously participate in what can be regarded as a form of collective deliberation leading to the settlement of a legal issue. ${ }^{9}$ There is authentic cooperation among

\footnotetext{
${ }^{8}$ This practice can be observed, for example, in the decision rendered in the United States in Atkins v. Virginia, 536 U.S. 304 (2002).

9 This was the practice followed in the South African cases Du Plessis ø. De Klerk, 1996 (3) SALR 85o; State v. Solberg, 1997 (4) SALR nz6; Premier, Kwazulu-Natal v. President of the Republic of South Africa, I996 (I) SALR; Bernstein v. Bester, 1996 (2) SALR 75г; and Minister of Finances $ง$. Van Heerden, 2004 (II) BCLR п25, to name but a few. The 'dialogue' metaphor is a metaphor widely used today in legal doctrine in order to give a unitary account to the many different ways in which courts ultimately resort to foreign legal contents. In keeping pace with a widespread doctrinal tradition (that is well summarised in G De Vergottini, Oltre il Dialogo tra Corti: Giudici, Diritto Straniero, Comparazione, (Il Mulino 20I0), for instance),we use the metaphor to refer only to the situation in which different courts belonging to formally distinct legal systems mutually refer to the precedents established by other courts in a consistent way, by so contributing to set up a procedure of informal collective' adjudication, so to speak, even in the absence of any formal obligation. An example of a dialogue between courts (as it is understood in this contribution) is the so-called 'multi-level' protection of human rights in the European space that has been provided by the (informal) coordinated effort of the Court of Justice of Luxembourg and the European Court of Human Rights of Strasbourg. Whilst those courts formally belong to different systems, they have embarked into a process of mutual coordination through the practice of cross-citation, which practice has in turn contributed to generating a convergent vision of human rights on this process see S Douglas Scott, 'A Tales of Two Courts: Luxembourg, Strasbourg and the
} 
courts in this scenario, in that they operate in different legal systems and so are not bound by any formal hierarchical relationship. Forms of mutual recognition and even cross-citation (the previously mentioned practice where courts in one legal system resort to precedents set in a different system, and at the same time see their own precedents invoked by courts in that other system) may thus emerge.

The practice of relying on foreign precedents, therefore, reveals itself to be a variegated and multifaceted phenomenon. Yet, for all this diversity, the practice can also be observed to share at least two elements common to all its forms. In the first place, in order for courts in different legal systems to be able to interact - whatever form such interaction may take (mere citation, one-way engagement, or genuine 'dialogue') - the different systems must share some fundamental legal traditions and general principles of law. Courts, in other words, tend to look to the jurisprudence of legal systems that share with their own systems more than just a few marginal features. In the second place, unless a court is hierarchically subordinate to the one whose precedent it appeals to, the force of that precedent is most likely not going to be binding, but at most persuasive. In fact, recourse to foreign precedents is generally regarded as legitimate but not mandatory: while a court may well invoke precedents set in foreign systems, it is under no obligation to do so, and these precedents will not carry the force of law in the domestic system (a domestic court may disregard them if it finds that they do not capture any superior wisdom).

In this practice of transnational judicial communication, much of the attention usually goes to the supreme courts and constitutional courts of certain countries, as well as to certain international courts, whose jurisprudence has accordingly come to form what appears to be a global judicial repository. This repository is widely consulted, and recourse to it often appears decisive in determining the outcome of a case, even though the domestic courts that draw on that case law belong to legal systems that on the whole may be markedly different from the one where the precedent was set.

There seems to be little to object to, at least on an intuitive level, in the rationale behind the practice where precedents circulate across the

Growing European Human Rights Acquis', (2006) 43 Common Market Law Review 629 ). 
world: it makes sense, when facing a hard case, to try and learn from comparable legal cases, and from the arguments deployed by other trained professionals in dealing with them, whenever and wherever these are available. The same ideal of cognitive and decision-making efficiency that justifies recourse to domestic precedent can be extended to the use of foreign precedents too. Apparently, if this justification for recourse to foreign precedents is to stand, the practice of turning to them cannot be perfunctory (mere citation), but must be fully engaged (ie it must be accompanied by thorough analysis), precisely because such precedents are not formally binding, which makes it all the more important to lay out the reasons that make them pertinent and compelling.

Still, as much as recourse to foreign precedent in domestic adjudication may be a time-honoured, widespread, and prima facie justified practice, it continues to spark a great deal of debate and controversy. On the one hand, we will find praise for a court's reliance on foreign precedents even without any formal obligation to do so. ${ }^{10}$ On this view, the practice concretises a valuable idea of judicial transnational cooperation that facilitates the circulation and sharing of legal wisdom. There is nothing objectionable about the use of foreign precedents, especially if the aim is not to mechanically import a specific rule from abroad, but to arrive at a better understanding of the case in question. In other words, it is hardly surprising that the same set of facts should find a consistent legal interpretation across judicial boundaries on the part of judges whose legal background and training is roughly similar, and it is not improbable (in light of those premises) for their legal analyses to be mutually illuminating. So, when it comes

${ }^{10}$ Recourse to foreign precedents in legal adjudication has been defended by D Beatty, 'Constitutional Rights in Japan and Canada' (r993) 41 American Journal of Comparative Law 535; D Beatty, 'Law and Politics' (r996) 44 American Journal of Comparative Law i3ı; C Steiker, 'Pretoria, Not Peoria: FCIS S . Makwayanyane r995 (3) SALR 39г' (1996) 74 Texas Law Review r285; and S Levinson, 'Looking Abroad When Interpreting the U.S. Constitution: Some Reflections' (2004) 39 Texas International Law Journal 353, and J Waldron, 'Foreign Law and the Modern Jus Gentium' (2005) in Harvard Law Review 129, among others. The practice has also been defended by judges both in the United States - with Calabresi (see, eg United States v. Then, 56 F3.d 464 (2nd Cir. 1995), at 469), S Day O'Connor, 'Broadening Our Horizons: Why American Lawyers Must Learn About Foreign Law' (1998) 45 Federal Lawyer 20 and S Breyer, 'Keynote Address' (2003) 97 American Society of International Law Proceedings 265, 266 - and in Canada, with L'Heureux-Dube (see, eg The Queen ง. Elshaw [I99I] 3 S.C.R. 24). 
to finding a basis on which to rest a solid legal qualification of a given dispute, a previous decision can prove valuable even if it comes from a foreign court. At the same time, recourse to foreign jurisprudence may prove to be a wholesome exercise in modesty: it is not indiscriminate that judges will look abroad in deciding a case, nor is the point to make a display of judicial acumen and learning. Quite the contrary, what prompts such recourse is a realisation that domestic law may be inadequate to the task - silent, unclear, vague, indeterminate, even contradictory in relation to the facts in question - or that the judge personally lacks the skills and intellectual resources needed to decide the case in a satisfactory way. In view of these limitations, which are both objective and subjective, it seems quite reasonable to engage with the way that other judges in other legal systems have decided a given question, especially when those systems are rooted in legal traditions comparable to one's own and rest on compatible fundamental legal principles.

On the other hand, there are legal practitioners and theorists who stand firmly opposed to the practice of resorting to foreign jurisprudence." A legal system, they claim, is the product of unique institutional histories, specific legal traditions, political arrangements not amenable to generalisation, and locally coloured social relations. Legal norms and institutions emerge from historical, cultural, and social ties that shape a people's national identity under a given jurisdiction. Since even superficial similarities between legal traditions and disciplines are bound to dissolve on closer scrutiny, any crosscultural intervention aimed at assimilating legal categories, traditions, institutions, and provisions to one another will ultimately show itself to be ungrounded and arbitrary. So, far from being a case of benign legal cross-fertilisation, the use of foreign precedents in judicial decisionmaking should be understood as a form of legal 'transplantation'. Like

\footnotetext{
"Among the number of those opposing the practice one may include $\mathrm{R}$ Alford, 'On the Limits of "Grand Theory" in Comparative Law' (I986) 61 Washington Law Review 945; R Alford, 'Misusing International Sources to Interpret the Constitution' (2004) 98 Agora 57; and E Young, 'Foreign Law and the Denominator Problem' (2005) Ir9 Harvard Law Review 148. Practitioners who criticise the use of foreign precedents in domestic adjudication are Justice Scalia (cf. Thomson v. Oklahoma, 487 U.S. 8ı5, at 868-9, for instance; see also his 'Foreign Legal Authority in the Federal Courts' (2004) 98 American Society of International Law Proceedings 3o5) in the US and Justice LaForest (cf. The Queen v. Rahey [1987] i S.C.R. 588, just to make one example) in Canada.
} 
any attempt to export something uniquely bound up with a given domain so as to transplant it into a different domain, judicial reliance on foreign precedents involves a great degree of discretion, thus lending itself to the creation of atypical constructs. In this sense it proves to be a largely uncontrollable activity. For this reason, the practice in question should be considered inherently subjective and fundamentally unjustified.

In sum, recourse to foreign precedent in legal adjudication is at once widespread (courts in many legal systems we are familiar with routinely engage in this practice) and controversial, in that legal practitioners, commentators, and theorists are deeply divided over the question whether the practice is legitimate, reasonable, or even expedient. In what follows, then, we offer a closer discussion of the theoretical assumptions involved in the practice. This will make it possible to bring the practice under critical scrutiny and may help us not only to understand what is at stake in the debate, but also to bring in our own alternative proposal, which lends qualified support to the practice.

\section{The DOMinant VIEW}

Currently most legal practitioners and scholars in the Western world believe that foreign precedents should be distinguished and treated differently from domestic precedents. On this view, domestic precedents are formally binding (at least in common law systems): every court is bound to follow the precedents set by any higher-ranked or equally ranked court that has already decided a case of the same kind. ${ }^{2}$ A foreign precedent, by contrast, is said to have merely persuasive force. There is no obligation to follow it, or at least it having been set in the past is not in itself ground on which to make it binding.

${ }^{12}$ The formal binding force of domestic precedents is not absolute, or exceptionless. Lower courts are on occasion allowed to depart from a precedent by distinguishing it, that is, single out features of an earlier case in such a way as to attenuate its precedential effect, thus making it irrelevant to the case at hand. Similarly, later courts are allowed to overrule previous decisions that can be argued to be extremely wrong or to have serious implications. Apart from those exceptions, however, domestic precedents are, to put it in the legal vernacular, sources of law. For an introduction to the standard doctrine of domestic precedents, see L Alexander, 'Precedent' in D Patterson (ed), A Companion to the Philosophy of Law and Legal Theory (Blackwell i996), 5o3; G Lamond, 'Precedent' (2007) 5 Philosophy Compass 699; and F Schauer, Thinking Like a Lawyer: A New Introduction to Legal Reasoning (. Harvard UP 2009), 36. 
Related, the impact of a foreign precedent on future cases depends exclusively on its soundness, as evidenced by its ability to convince courts in a different legal system that it has been decided correctly as a past case identical to the present one in all relevant respects.

The view just introduced assumes a rigid dichotomy in dealing with precedents, or a clear demarcation between domestic and foreign precedent, which in law are claimed to operate differently. This dualist approach we will henceforth refer to as the 'dominant view', since it not only underpins a significant amount of academic studies of precedent-based adjudication, but is also adhered to by most practitioners, especially judges. ${ }^{13}$ Crucially, the dominant view's distinction between types of precedents is instrumental to justifying the claim that courts should be wary of relying on foreign precedents in settling domestic disputes. There are at least two main reasons why those embracing the dominant view regard the appeal to foreign precedents as problematic (at least presumptively).

The first of these is that the practice turns into domestic law what is essentially foreign law: it does so almost by definition, since the practice consists precisely in bringing a domestic case under the rule of a foreign precedent, which in a strict sense cannot be regarded as part of the legal system within which the dispute arose. This raises a problem because non-domestic law, on the dominant view, does not qualify as law to begin with (not from the domestic point of view): it must (from that point of view) be treated as extra-legal material, in the literal sense that it lies outside the boundaries of what a domestic system can recognise as its own law. It follows that to resort to foreign precedent is ultimately to blur the distinction between what is legal and what is extra-legal: it amounts to indirectly justifying the practice of adjudicating cases - that is, determining what the law says in regard to those cases - in light of non-legal material, inclusive of social norms, moral standards, and policy considerations, among other things. ${ }^{1 / 4}$ This

\footnotetext{
${ }^{13}$ Among the advocates of the dominant view one may include G Fletcher, 'The Universal and the Particular in Legal Discourse' (1987) 2 BYU Law Review 335; G Fletcher, 'Constitutional Identity' (1993) ı4 Cardozo Law Review 737; F Schauer, 'Free Speech and the Cultural Contingency of Constitutional Categories' (I993) I4 Cardozo Law Review 865; R. Posner and C. Sunstein, 'The Law of Other States' (2006) 59 Stanford Law Review ı3ı; and F. Schauer, 'Authority and Authorities' (2008) 94 Virginia Law Review i93ı.

${ }^{14}$ Accordingly, G Smorto, 'L'Uso Giurisprudenziale della Comparazione' (20I0) I
} 
cannot but strike us as contradictory if we follow that logic closely. So, the argument here is that by introducing into one country the law in force in another country - governed by another set of rules and institutions set in a different political context - the use of foreign precedent in judicial decision-making winds up making judicial reasoning ultimately indistinguishable from practical reasoning at large. That, on the dominant view, is an illegitimate intrusion of external influences in a sphere, the legal domain, which should maintain an identity of its own.

The second problem the dominant view has with recourse to foreign precedent lies in the discretionary vacuum within which the practice ordinarily takes place. Indeed, in most cases there is no express obligation to have recourse to foreign precedents, nor is there any set of principles on which basis to (a) determine whether to have such recourse and, if so, (b) select the proper precedent. The problem here is not so much the use of foreign precedents per se as the ability to make any decision in that regard on whatever basis seems reasonable enough, without reference to any agreed framework for making such choices. In exercising this ability to 'shop around' in search of the best foreign precedent, courts essentially gain the power to choose the grounds on which a case is to be decided. This is too much discretion far greater than one should accept as part of the regular process, or 'physiology', of legal adjudication, for it becomes a breeding ground for creative judicial decision-making. Since there is no rule mandating appeal to foreign precedents in legal adjudication the practice is permissible but not obligatory), nor is there any rule under which to determine which precedents ought to govern in any given case, different courts are going to use that discretionary power in different ways in deciding cases brought before them. The consequence of this

Europa e Diritto Privato 223, and G De Vergottini, Oltre il Dialogo tra Corti: Giudici, Diritto Straniero, Comparazione (Il Mulino 20го) I/40, distinguish at least three different uses of foreign precedents in judicial adjudication: a) a purely 'ornamental' use of precedents, that takes place when the justification can be considered sound and complete even without the quotation of the relevant foreign precedent (which, therefore, from a logical point of view adds nothing to the decision); b) a 'normative' use of precedents, wherein the decision of the present case is the direct application, or emanation, of the rule embodied in some foreign decision; c) a 'dialectical' use of foreign precedents, which occurs when the court refers to the factual reconstructions made in the justification of the foreign precedent in order to get a better understanding of the domestic case at stake. 
state of affairs is that controversies of the same type may wind up being decided on different legal grounds within the same legal system. As a result, we end up with a scenario of reduced control of legal adjudication, making for a less certain process given to greater unpredictability of outcomes.

Even when the critical arguments just outlined do not altogether disqualify the practice of resorting to foreign precedent, they do suggest caution: they point up the need to introduce strict criteria governing and limiting the use of foreign precedents so as to make that use legitimate. On the dominant view, three such criteria are typically held up. First, recourse to foreign precedent is legitimate only when the body of domestic law is inconclusive, particularly when interpreted literally or in accordance with the legislator's original intention. This means that appeal to foreign precedent is legitimate, if its use serves the purpose of filling gaps in domestic law: it is not legitimate as a way to overturn or bypass a holding issued on the basis of domestic law (that is, as a technique of judicial activism). ${ }^{5}$ Second, courts may not proceed ad hoc in making decisions about the relevance of foreign precedents to domestic cases: they must proceed in a consistent manner, in keeping with a doctrine of foreign precedent having a degree of generality and comprehensiveness comparable to that which characterises doctrine of domestic precedent. ${ }^{16}$ Third, if a court does decide to resort to foreign precedent as a basis on which to settle a domestic case, it cannot borrow from any legal system of its own choosing: the precedent appealed to ought to be one set in a legal system whose institutional framework and fundamental legal principles are similar to, or at least consistent with, the domestic legal system in which the case is being heard. The rationale for this requirement is that a precedent does not exist in isolation from the legal system it is part of. So, a precedent at least indirectly bears the mark of the institutional framework it is derived from. This in turn means that through the practice of deciding a domestic dispute on the basis of legal materials originating in a foreign system, we not only inject a specific rule of foreign law into the domestic system but also, more

\footnotetext{
`5 This is a view defended in M Lupoi, Sistemi Giuridici Comparati (EDS 2001) and G Smorto, 'L'Uso Giurisprudenziale della Comparazione' (20I0) I Europa e diritto privato 223, among many others.

${ }^{16}$ This view is defended in M Ramsey, 'International Materials and Domestic Rights: Reflections on Atkins and Lawrence' (2004) 98 Agora 69, for instance.
} 
problematically, we bring in a whole set of accompanying institutional arrangements, general principles, and justificatory arguments. Accordingly, the more alien the foreign system, the greater the likelihood that the importation of foreign precedent will give rise to normative inconsistencies, local ones, but also conceivably deeper ones, precisely because to import a single rule or precedent is to import its underlying or system-wide rationale. Hence the need for courts to limit the reservoir of foreign law from which to draw by selecting only those precedents whose enveloping legal system is similar to the domestic one not just on the surface or in a broad sense, but on a foundational level too.

Now, in order for one to get a full sense of this set of restrictions on a court's reliance on foreign precedent, one has to dig deeper and consider the theoretical assumptions underpinning the dominant view. We submit that the dominant view of foreign precedents needs to be viewed in light of a broader conception of the legal system and of the reasoning and authority associated with it. ${ }^{7}$ On this conception, which one may want to categorise as sociologically oriented and broadly positivistic, the law is understood primarily as a set of issuances coming from the political institutions linked to a given domestic jurisdiction. Law is the 'will' of a political institution: it is the expression of a sovereign power through which a rule becomes legally valid and socially effective. From the standpoint of one who is committed to these claims, the problem with the use of foreign precedents is that foreign precedents are not issued by the political institutions empowered to make (the rest of) the law in a given jurisdiction. ${ }^{18}$ When courts appeal to foreign precedents in deciding disputes, they are not relying exclusively on the law created by, or traceable to, the institutions entrusted with law-making in their own legal order. Accordingly, from the standpoint of one who conceives of the law as the product of the political institutions endowed with

\footnotetext{
${ }^{17}$ We should add here that this broad conception is not always made explicit by those who urge caution in appealing to foreign precedents in legal adjudication. Therefore, the reader should be aware of the fact that in these pages we are in fact reconstructing and reinterpreting the theoretical assumptions underpinning the dominant view, as opposed to describing those assumptions as they have expressly been set out by the advocates of the dominant view.

${ }^{18}$ This point is made most clearly by a critic of the dominant view, $\mathrm{J}$ Waldron, in his 'Foreign Law and the Modern Jus Gentium' (2005) ing Harvard Law Review 129-47, I $46-7$.
} 
authority in a given jurisdiction, the practice of appealing to foreign precedents in adjudication finds no straightforward justification, since it can be argued that the practice itself eventually resorts to an unwarranted use of extra-legal material in adjudication. ${ }^{19}$ The point can be restated from a different angle by noticing that what on the dominant view makes the recourse to foreign precedent objectionable is that the practice ultimately severs legal adjudication from the law. However, this amounts to making legal adjudication an activity whose nature is at least partly non-legal. Moreover, one can see the contradiction this statement seems to give rise to: how can we legitimately call 'legal' a form of adjudication that largely proceeds independently of the law?

These remarks show that the dominant view is grounded in the conception of a legal system as a closed and self-contained space: a geographically delimited domain that can be kept distinct from the outside world. A legal system, in other words, singles out a territorial entity only moderately and partly permeable to external influences: each legal system is largely independent of the other systems of laws, understood as demarcating altogether different institutional spheres. Overlaps between different systems of law must therefore be kept to a minimum, for otherwise it would no longer be possible for those systems to retain the separation that on the dominant view constitutively defines the identity of law. ${ }^{20}$ What is problematic about recourse to foreign precedent in legal adjudication, then, is its blurring of the boundaries of a legal system, which accordingly wears away at its identity and independence. By importing foreign decisions and modes of reasoning into the domestic system, recourse to foreign precedent makes permeable the wall of separation between what is inside the system (law) and what is outside (non-law). For this reason the recourse

${ }^{19}$ Indeed, on the sociologically oriented and positivist conception, anything not traceable to domestic law-making institutions must be regarded as non-legal material or, stated otherwise, nothing that is not created by such domestic institutions can be counted as law.

${ }^{20}$ As a matter of fact, some regard the distinction between in and out - what is inside a legal system and what falls outside - as a defining element not only of a legal system but also of the very idea of law. The radical variant of this claim amounts to the socalled 'limited domain thesis', which is a fundamental tenet of legal positivism (cf. J Raz, 'Postema on Law's Autonomy and Public Practical Reasons: A Critical Comment' (I998) 4 Legal Theory $\mathrm{I}-20$, for instance) and has found a recent revisionary statement in F Schauer, 'The Limited Domain of the Law' (2004) 9o Virginia Law Review rgog. 
to foreign precedents can be legitimised only if exceptional and subjected to a rigorous internal discipline.

This broad conception of the legal system is in turn inextricably bound up with a specific model of legal authority: the model that depicts legal authority as an institutional arrangement whose directives are to be obeyed not on the merits, but simply because they issue from those arrangements. One can see that this conception of legal authority cannot easily be made to cohere with the practice of recourse to foreign precedent, for the force associated with foreign precedents is not procedural or formal, but rather persuasive. Legal adjudication based on foreign precedents is thus primarily a matter of reasoning one's way through disputes and controversies, as opposed to following directives that are formally valid and binding just because they come from certain bodies. Whenever courts appeal to a foreign precedent, they resort to a substantive argument aimed at convincing the parties, as well as the legal community at large, that the settlement of a given dispute is convincing by virtue of its content. To the extent that foreign directives are content-based - or to the extent that they rely on content-dependent reasons that take precedence over formal, contentindependent reasons - their introduction into the domestic system is liable to undermine its authority (in the formal sense being explained), a circumstance that seems intuitively puzzling, considering that law ought to be a paradigmatic instance of an authoritative institution.

\section{An Alternative Perspective}

Thus far we have noted that, on the dominant view, foreign precedents do not have equal standing with domestic precedents: whereas domestic precedents are formally binding and their use is mandatory, foreign precedents have conditional persuasive force and their use is merely permissible. The dominant view can in this sense be said to offer a radical two-tiered account of precedent in law, where one type of precedent (the domestic) is recognised as a binding source of law, while the other type (the foreign) at best rises to the rank of a source that may, but need not, be relied on in legal adjudication. We submit that this dualism informing the whole dominant view is problematic, for it can encourage practices that have us distinguish law from nonlaw in an arbitrary and rigid way, making for a sort of conceptual

schizophrenia in handling the two. In this section we intend to offer an 
alternative approach to the practice of appealing to foreign precedent. In so doing, we also lay the basis for an integrated account of precedents that significantly reduces the gap the dominant view sees between domestic and foreign precedents. This will make it possible to subject the two types of precedent to different conditions of use, while giving them an equal status as authoritative sources of law, sources that courts are not only entitled but also expected to appeal to in adjudication.

We will argue for our alternative conception by first introducing its fundamental theoretical presuppositions and then proceeding to bring those presuppositions to bear on the specific debate on the use of foreign precedents in law. ${ }^{2 .}$ The two treatments are meant to work in combination: the theoretical presuppositions are introduced as part of a discussion of their role in the claims made about foreign precedents, for in this way we can provide the foundations on which to rest a conception that, if coherently developed by bringing out its implications, can become general enough as a framework within which to address the full range of essential questions traditionally discussed in connection with the practice of resorting to foreign precedents in legal adjudication.

The nature of the conception we introduce is primarily normative, and the ensuing discussion of foreign precedent should also be understood that way. As much as we may start out from current legal practice in our investigation of recourse to foreign precedent in legal adjudication, our primary concern is not to explain these practices (such as they exist), but to understand how reasoning with foreign precedent in law ought to proceed in order for it to be justified. In a nutshell, then, in what follows we lay out a normative and theoretical account that both idealises and abstracts from actual adjudication practices based on the use of foreign precedents. This means that the account we present will be designed to provide a basis on which to distinguish justified recourse to foreign precedent from a recourse that is not justified. We will do so in particular by offering a theory of sound reasoning with foreign precedent in law, namely, a theory pointing out a mode of

\footnotetext{
${ }^{21}$ We have chosen to so organise our exposition, in that order, because we believe that only by making the theoretical assumptions underpinning our view explicit will it be possible to work out a truly alternative way to approach foreign precedent in law.
} 
argumentation that courts should use vis-à-vis foreign precedents.

\section{Dialectical Model for Legal Reasoning}

As was just remarked, our project consists in contributing to a theory of legal reasoning setting out the conditions subject to which the citation of foreign precedents can be justified. The natural place from which to start is a discussion about the nature of reasoning in legal adjudication. To anticipate the basics of our proposal, it is our view that legal reasoning in the courtroom should properly be considered a dialectical exercise: an argumentative exchange between the prosecutor and the parties in a courtroom. ${ }^{22}$ Our hypothesis, therefore, is that what determines the soundness of legal reasoning is a discussion-based, or dialectical, ideal. This ideal is in turn defined and partly determined by the principles of discursive rationality, that is, by the standards of reason on which any debate in the practical domain rests, and absent which there could be no exchange of views involving a decision on a matter of common interest. So, legal reasoning will be understood here as a dialectical activity geared towards solving legal disputes amenable to a discursive solution. This concise statement of our position requires some further elaboration and argument.

We begin with the understanding that legal reasoning - by which phrase, unless otherwise specified, in this essay we mean the activity of

${ }^{22}$ From here on out, and unless stated otherwise, the term legal reasoning will be used to refer to the whole of the deliberative activities that take place in courtroom proceedings. We do realise that in common parlance "legal reasoning" has a much broader meaning and it is not confined to deliberative activities engaged in by judges, prosecutors, and the parties in a courtroom setting - for forms of legal reasoning are also undertaken outside the courtroom by academics, laypeople, and the media. We also agree that for many purposes a broad conception of "legal reasoning" - a conception under which legal reasoning is understood as any deliberative activity that is concerned with legal standards and is carried out by any subject (be it a legal scholar, a public official, a practitioner or a layperson) - is fully justified and acceptable. We make use of a narrower conception - the conception that "legal reasoning" stands for the activity of reasoning, argument and deliberating in a courtroom - in this essay in order to delimit the concern of our argument by thus making it both clearer and more manageable. We would like to think, even if we are unable to show this here, that the account of legal reasoning we present can itself be expanded so as to cover that broader range. Anyway, the reader should be aware that our decision to reserve the phrase "legal reasoning" to a specific subset of deliberative activities is understood as a purely terminological stipulation bearing no substantive, or theoretical, implication. 
reasoning, arguing, and deliberating in a courtroom - paradigmatically consists in, and can be reconstructed as, a series of communicative exchanges between parties arguing for competing normative theses and providing evidence for alternative reconstructions of the facts. The structure of these exchanges is adversarial, in that they are conducted under a procedure designed to give all parties a fair shot at laying out their arguments and counterarguments: the claims made by one party (the proponent) are challenged by the other party (the challenger); the proponent will then rebut by looking for flaws in the challenge or seeking to take it down altogether, at which point the challenger will be expected to defend the challenge so criticised, and so on. In this adversarial procedure lies the basic structure of reasoning in courtroom proceedings. The structure of legal reasoning can thus be described at its barest as an adversarial succession of speech acts performed in a courtroom by parties who for all practical purposes can be equated with discussants. This is the basis on which we claim that legal reasoning ought to be conceived as dialectical.

The dialectical exchanges constitute, and at the same time are made possible by, the adversarial procedures by which argumentative activity in the courtroom is structured. Their relevance for the construction of a rational decision cannot be overstressed. An adversarial procedure sets one party against another, both of whom are guaranteed equal rights and duties. Starting from this position of formal equality, the parties in an adversarially structured courtroom proceeding will be attempting to convince each other that the claims they made are grounded and so should be accepted by everyone. At the same time, the opponent's view would be shown to be unacceptable or even absurd or inconsistent. On this view, adversarialism not only captures the core of reasoning in law, but also provides the source of its justification. This is because adversarial procedures are not simply structural methods enabling parties to settle a dispute in an orderly fashion, but, more importantly, they are to be understood as intrinsically valuable from an epistemic point of view: they can be shown to be the most reliable strategy we have to achieve the regulative ideals of normative correctness. In view of the constitutive partiality and inherent situatedness of any single perspective, the search for normative correctness eludes the efforts of particular individuals. The prosecutor and the parties, considered in isolation from each other, can hardly aspire to move beyond their own qualified notions of 
correctness, which is intrinsically one-sided and thus ultimately incomplete. This means that the discursive exchanges shaped by adversarial procedures are equipped to connect otherwise partial viewpoints, while putting them to the test to see if they stand up to scrutiny. By enabling prosecutor and parties to state and defend their claims, while giving them an opportunity to challenge the position held by the counterparty, courtroom debates based on adversarial procedures and mutual confutation take us a step closer to what is normatively correct in the practical domain. ${ }^{23}$ The conception just outlined frames legal reasoning as a collective deliberative exercise. In this framework, the prosecutor, the parties, and the judge each play a fundamental role in shaping the structure and outcome of reasoning in legal adjudication. Legal reasoning is thus a three-party affair. ${ }^{21}$ On the one hand, one can hardly overemphasise the essential role played by the prosecutor and the parties in the activity of reasoning in law. The prosecutor and the parties put forward arguments and set out to counter each other's claims. They do so by asking questions, replying to queries, offering narratives, interpreting norms, and collecting evidence, among other activities. On the other hand, one should not underrate the role of judges, in shaping reasoning in the courtroom, since they are entrusted with the essential task of supervising the discursive exchanges between the prosecutor and the parties. Indeed, at a minimum the judge will be acting as a referee, overseeing the communication between courtroom discussants. Even though this may be reconstructed as a passive, spectator-like role, the fact that the judge is presiding as an expert spectator, entrusted with making sure that the parties are proceeding in the right way in challenging each other's claims should not be downplayed. This, in turn, brings into focus the judge's structural role in the proceedings: the judge is primarily there to structure and organise the exchange between the parties, correct any

${ }^{23}$ On this view, normative correctness is secured by, and anchored to, the adversarial structure of legal deliberation in court. In other words, normative correctness is not defined by, and grounded in, some pre-established authority. The justification and binding force of normative conclusions transcend the boundaries of the specific controversy; there is no external social fact or practice that can ground the correctness of the normative conclusions drawn in legal adjudication. This position is argued at length in F Cavalla, La Prospettiva Processuale del Diritto (CEDAM i99i), 36-45 and F. Cavalla, Retorica Processo Verità (Franco Angeli 2007). For a philosophical foundation of this position, see O O'Neill, Constructions of Reason (CUP I989), 28.

${ }^{24}$ In De iudiciis, Bulgarus accordingly describes legal reasoning as an actus trium personarum. 
substantive disparity hidden behind the formal equality, weigh in with legal expertise and experience, and see to it that the overall adversarial procedure does not depart from its dialectical logic. So, central to reasoning in law, on a dialectical approach, is the critical exchange, or debate, in which narratives and normative interpretations are put forward as valid and are subjected to scrutiny, where they are challenged, a process in which they may be falsified or shown to be untenable. We can see, thus, that the discussion carried out in a courtroom proceeding can hardly be resolved into a two-party confrontation: it is an adversarial engagement that unfolds under the watchful eye of a third party, the judge, acting as a 'guardian' of the fundamental principles by which debate, qua dialectical exchange, is governed in the courtroom, or by which reasoning is constitutively and essentially shaped in legal adjudication.

In sum, reasoning in law, on a dialectical approach, is paradigmatically an activity aimed at settling a dispute under the oversight of a judge mediating the exchange that unfolds in a courtroom between prosecutor and parties. The outcome of a legal controversy thus emerges gradually and requires the participation and interchange of prosecutor, parties, and judge. No outcome can be regarded as correct - that is, acceptable by any rational discussant - unless the reasons proffered by the prosecutor and the parties in legal deliberation are heard and scrutinised, a process through which they will either be found to carry weight in a judicial decision or will be shown to be untenable. ${ }^{25}$

Now, discussants engaged in discursive interaction or deliberative activity may well disagree on how the legal disputes at hand ought to be settled (and in fact disagreement is typically the norm). However, their participation in adversarial procedures aimed at dealing with those disagreements at least implicitly commits them to certain standards of practical rationality. These are the standards that state the conditions for the very possibility of dialectical interaction among individuals having different interests and objectives. For absent a set of rational criteria, which by virtue of their being constitutive of adversarial, or dialectical, exchanges also regulate those exchanges from within and so amount to inherently normative standards, there can be no dialectical process; meaning that there can be no discourse

${ }^{25}$ An insightful discussion of these questions can be found in $\mathrm{P}$ Sommaggio, Contraddittorio, Giudizio, Mediazione (Franco Angeli Sommaggio 2012), 129-66. 
aimed at settling controversies. This is to say that any practical discourse aimed at solving disputes is a distinctive form of engagement whose identity is defined by criteria of rationality acting as necessary presuppositions lacking which practical discourse itself as a form of deliberation would not be possible to begin with. ${ }^{26}$

The standards of practical reason implicit in dialectical exchange frame an ideal that can be described as discursive rationality, since those standards define a specific activity, namely, discourse, or deliberation. ${ }^{27}$ Thus understood, discursive rationality is a form of communicative rationality: it refers to the principles underlying the discursive exchanges through which different views are put forward, conflicting claims are asserted, and disputes are settled. Discursive rationality thus emerges as an arrangement of principles that any practical argument needs to satisfy as a necessary presupposition. Among these principles, which govern the discursive moves in any form of communication aimed at subjecting some viewpoint to critical scrutiny, we should at least find the principles of consistency (or logical non-contradiction), coherence (both narrative and normative), and universalisation. ${ }^{28}$ This

${ }^{26}$ For a comprehensive treatment and justification of this view, see $\mathrm{F}$ van Eemeren and R Grootendorst, Speech Acts in Argumentative Discussions (Foris 1984) and F van Eemeren and R Grootendorst, 'Rationale for a Pragma-Dialectical Perspective'(1988) 2 Argumentation 27I. This general approach is contextualised in the study of legal reasoning in E Feteris, 'Conditions and Rules for Rational Discussion in a Legal Process: A Pragma-Dialectical Perspective' (r990) 26 Argumentation and Advocacy ıo8; E Feteris, 'Rationality of Legal Discussions: A Pragma-Dialectical Perspective' (1993) XV Informal Logic ı79; J Plug, 'Reconstructing Complex Argumentation in Judicial Decisions' in F van Eemeren and R Grootendorst (eds), Studies in PragmaDialectics (SicSat 1995), 246, and S Bertea, 'The Arguments from Coherence' (2005) 25 Oxford Journal of Legal Studies 369.

${ }^{27}$ The idea of discursive rationality finds a thorough discussion in the works of KarlOtto Apel and Jürgen Habermas. See, in particular, KO Apel, 'Das Apriori der Kommunikationsgemeinschaft und die Grundlagen der Ethik' in Transformation der Philosophie vol. 2 (Surkhamp I973), 358-35; J Habermas, The Theory of Communicative Action, vol. I (McCarty ig8r); J Habermas, The Theory of Communicative Action, vol. 2 (McCarty I984); J Habermas, The Tanner Lectures on Human Values, vol. 8 University of Utah Press I988); and J Habermas, Moral Consciousness and Communicative Action (MIT Press I990). The discursive approach to reasoning is applied to law and legal reasoning in $\mathrm{R}$ Alexy, A Theory of Legal Argumentation (Clarendon Press 1989, or edn 1978), 177-295.

${ }_{28}^{8}$ A discussion of these criteria of rationality can be found in A Aarnio, R Alexy and A Peczenik 'The Foundation of Legal Reasoning' (I98I) 2I Rechtstheorie I33-58, 259-73 and 423-48; F Cavalla, 'Della Possibilità di Fondare la Logica Giudiziaria sul Principio di non Contraddizione' (1983) I2 Verifiche 5; A Aarnio, 'Why Coherence: 
means that legal reasoning - understood as a sequence of discursive moves structured around adversarial procedures - can be characterised as sound when it at least lacks internal contradictions, is overall coherent, and can be accepted by others solely on the basis of universalizable reasons or arguments advanced in support of its conclusions. So, the two basic features of sound reasoning are that its conclusions should not be contradictory (either with each other or with their premises) and that everyone who uses its principles should have to acknowledge those conclusions as correct. ${ }^{29}$

The principles just introduced can be regarded as rational in that a failure to follow them makes inconceivable any debate aimed at resolving disputes, and in some cases makes inconceivable the very practice of communicating. In much the same way as discussion is considered a rational way to settle controversies, we should consider rational the criteria by which practical discourse is regulated. So, it is by looking at the principles of discursive rationality that we can tell what forms of legal reasoning are correct: no legal dispute can be said to have found a legitimate solution if it was settled in violation of any of these principles. This means that sound legal reasoning can be characterised as a sequence of communicative exchanges carried out in keeping with the principles of discursive rationality.

Predictably, the principles of discursive rationality, as general and abstract requirements, do not conclusively determine the correct structures or the justified outcomes of deliberation in law: they are not formulas or algorithms that you apply to the premises of a dispute so as to self-sufficiently yield conclusions. They cannot on their own and in advance dictate the form, the substance, or the outcome of the deliberative practices carried out in accordance with them. Their role is structural in a rather more open-ended way, in that they only set the general boundaries within which legal reasoning can be characterised

A Philosophical Point of View' in A Peczenik (ed), On the Coherence Theory of Law ( Jiristförlaget i Lund r998), 33-9; R Alexy, 'Coherence and Argumentation or the Genuine Twin Criterialess Super Criterion' in A Peczenik (ed), On the Coherence Theory of Law ( Jiristförlaget i Lund 1998), 39-49; F Cavalla, 'Retorica, giudiziale, logica e verità' in F. Cavalla (ed) Retorica, Processo, Verità, (CEDAM 2007), 17-84; and P Sommaggio, Contraddittorio, Giudizio, Mediazione (Franco Angeli Sommaggio 2012), I80-204.

${ }^{29}$ On this point see, in particular, F Cavalla, La Prospettiva Processuale del Diritto (CEDAM I99I), 68-83. 
as sound. It follows that the principles of discursive rationality do not exhaust and replace actual debate in a courtroom proceeding; rather they set out the minimal conditions for a discussion to exist, and in so doing provide the method that needs be followed in order to embark on rational discussion. Hence, the normative framework so constructed - the framework outside which no discussion can take place - is context-dependent not only by virtue of its being compatible with any number of outcomes, but also in the more poignant sense that, in order to make it operative, the discussants need to bring into it the substantive presuppositions, or shared knowledge, forming the necessary background of the claims they make. These are what Aristotle called endoxa, the 'commonplaces' that make up our 'shared knowledge' or widely accepted beliefs. Endoxa act as general premises on which the (non-private) validity of the claims asserted by the discussants rests. Clearly, the endoxa one brings into the discussion are specific to the issue at hand, and so each rational discussion will have its own endoxa (and no genuine discussion can go without endoxa, either). The rationale of the appeal to endoxa can be thus summarised: endoxa can support the specific arguments that unfold in dialectical exchanges because they embody what deserves to be acknowledged once the social context in which a specific discussion is undertaken is taken due account.

To conclude, on the dialectical model introduced in this section, legal reasoning must satisfy the principles of discursive rationality, if it is to constitute a sound method for dealing with legal disputes. So, as much as the adversarial procedure framing the discursive exchanges made in courtroom proceedings is an essential part of the reasoning involved in legal adjudication, it does not, on a fully articulated dialectical approach, complete the picture of sound legal reasoning. For sound legal reasoning is more than a structured sequence of discursive exchanges, insofar as the latter need to be understood as part of an argumentative practice informed by the principles of discursive rationality. ${ }^{30}$

3o The fundamental tenets shaping the framework we theorise differentiate it from two influential theoretical approaches to legal reasoning that may arguably be interpreted as defending claims conceptually akin to those we theorise in this work, namely, the hermeneutical account of legal argument and the view of legal reasoning associated with Martin Shapiro's 'political jurisprudence'. The affinity between the theory we defend, the conception theorised by the champions of legal hermeneutics and the account advocated by Shapiro is due to the fact that they all 
deny the existence of a neat distinction between law and legal reasoning, on the one hand, and politics and practical decision-making on the other hand. In addition, they all pay specific attention to the processes of communication going on between the subjects who take part in the activities of legal deliberation. Finally, all three accounts agree, at least to some extent, that the use of foreign precedents is best understood as a way of coordinating and harmonising practices of adjudication that are carried out by units (namely, courts of different legal systems) inhabiting a space that is not informed by hierarchical structures (this point is formulated most clearly in M Shapiro and A Stone Sweet, On Law, Politics, and Judicialization (OUP 2002), 9o-Ior). In that respect, the three accounts may be argued to at least superficially converge on the view that the practice of appealing to foreign precedents ultimately constitutes a form of 'unhierarchically coordinated judge-made law' and that in the areas covered by that practice courts seek to achieve coordination through 'horizontal interstate stare decisis' and so they adopt a 'mode of non-authoritative legal communication' (M Shapiro and A Stone Sweet, On Law, Politics, and Judicialization (OUP 2002), 95). These elements set the three theoretical approaches apart from most of the other theories of legal reasoning supported nowadays. Despite this conceptual continuity, however, the account we offer can neither be reduced to legal hermeneutics nor be equated to Shapiro's theory of legal reasoning. The project undertaken by legal hermeneutics is best interpreted as aimed to provide a heuristic device for an adequate understanding of the forms of legal deliberation. As a result, the hermeneutical approach grants one invaluable insights on the actual pre-conceptions and specific pre-understanding affecting the interpretive processes framing legal adjudication. Related, it makes one acutely aware of the nature of those processes as well as their discretionary quality. Yet, contrary to the theory introduced in this section, legal hermeneutics is not directly concerned with the normative dimension of adjudication and so is unable to establish any normative standard for legal reasoning (for further remarks on the shortcomings of legal hermeneutics see F Zanuso, 'In Claris non Fit Interpretatio: las Ilusiones del Normativismo en la Critica del la Hermenéutica' in Aa.Vv., Hermenéutica Juridica: Sobre el Alcance de la Interpretaciòn en le Derecho (Comillas 20ıI), 255-75). The normative dimension is largely absent from Shapiro's proposal too. His political jurisprudence is programmatically meant to apply the principles of social sciences to the study of law (cf. M Shapiro and A Stone Sweet, On Law, Politics, and Judicialization (OUP 2002), 3-18). As a result, Shapiro's political jurisprudence is less a normatively oriented full-scale legal philosophy than a sophisticated and insightful contribution to behavioural social science that can be comfortably situated within the American realist movement (broadly understood) and related pragmatic turn in jurisprudence (paradigmatic in that respect is the treatment of the doctrine of precedent that can be found in M Shapiro and A Stone Sweet, On Law, Politics, and Judicialization (OUP 2002), IO2-II). On this basis, political jurisprudence present courts and judges as 'part of government', which as such 'must be studied empirically' (M Shapiro and A Stone Sweet, On Lax, Politics, and Judicialization (OUP 2002), 13). This feature neatly distinguishes Shapiro's peculiarly empirical approach to precedents in law from the account of precedents introduced in this paper, which, by contrast, is essentially characterised by the explicit endorsement of the normative standpoint - namely, the standpoint that is mostly absent in both 


\section{Dialectic and Reasoning with Foreign Precedent}

It was just remarked that the dialectical model of legal reasoning introduced in the previous section defines an argumentative practice necessarily informed by the principles of discursive rationality. It follows from that feature of the model that foreign precedents are presumed to have some kind of bearing on the cases at hand. Foreign precedents are here understood to comprise both the argument offered in support of a judicial decision and its substantive outcome. There is an intrinsic rationality to the practice of relying on past arguments and decisions in dealing with present issues. The intrinsic rationality of the practice is owed to the fact that precedents - including foreign ones result from past legal proceedings. Insofar as they are carried out in accordance with adversarial procedures enabling prosecutor and parties to engage in argumentative activities where the parties defend their own claims before the judge and argue against those put forward by the counterparty, legal proceedings have an inherent value. The inherent value of practices so framed lies in their being structured in a rational way rather than simply occurring as a series of events involving certain individuals and taking place in a certain place at a certain time and under certain conditions. Legal proceedings, in other words, do not exist as mere facts, but concretise the general and abstract principles of discursive rationality. It is for this reason - namely, because courtroom proceedings make it possible to decide disputes in a rational way - that the arguments and rulings contained in precedents are prima facie justified. They are justified, in other terms, by virtue of the presumptively rational manner in which they have dealt with a dispute in the past. Since, in the context of a legal proceeding, the judge, the prosecutor, and the parties learn a great deal by engaging with disputes decided beforehand in accordance with rational procedures, a foreign precedent can legitimately extend its effect to subsequent domestic cases so long as it can be found to have been correctly decided.

These introductory remarks show that, on a dialectical account informed by the principles of discursive rationality, foreign precedents are endowed with presumptive binding force. We call their binding force presumptive because it is ultimately conditioned upon the

legal hermeneutics and Shapiro's view. Hence the distinctiveness of the approach we set out to defend in this work when compared to the approaches to legal reasoning that show some continuity with our research programme. 
rational acceptability of both the previous deliberative activities carried out in the courtroom and their outcomes. It follows from that that the authority of a foreign precedent ultimately rests on how convincing the courts should find its argument and ruling. This admittedly blunt statement of the dialectical position that we endorse needs to be refined and qualified. On the one hand, the statement should not be taken to mean that the provenance of the precedent - foreign, as opposed to domestic - is completely irrelevant. On the other hand, it starts out from an idea of legal authority that can be seen to be instantiated by precedents. Both of these points call for further elaboration.

Let us take them up in turn and consider first the main issues relating to the provenance of a precedent. From a dialectical perspective shaped by the standards of discursive rationality, the bindingness of a precedent - be it domestic or foreign - is constructed in the process of carrying out a courtroom proceeding, where a prosecutor and the parties exchange arguments under a judge's control and supervision. This principle is general and so applies to domestic and foreign precedents alike. However, the argumentative burden one carries in resorting to these two types of precedent is not the same. As part of the same legal system where the present controversy has arisen, a domestic precedent can be presumed to apply to that controversy, provided that it can be argued to apply to a situation relevantly similar to the case presently before the court. A domestic precedent can accordingly be assumed to authoritatively apply to the present dispute, unless its relevance is challenged by one of the parties involved in the dispute.

The process by which to validate recourse to foreign precedents is, by contrast, more thorough and detailed. Foreign precedents cannot enjoy the same presumption that domestic ones do concerning their relevance and applicability. There is therefore an additional argumentative burden, peculiar and more demanding, that comes with the use of foreign precedents. This burden mainly consists in the requirement that an argument be produced showing that the foreign precedent at issue does not come from institutional contexts informed by legal traditions, principles, and norms incompatible with the ones shaping the legal system in which the present case is being decided. This means that, before foreign precedents can be used in adjudication, they need to be carefully introduced and systematically discussed in 
the courtroom. Such extensive debate offers the prosecutor, the parties, and the judge an opportunity to assess the soundness of a foreign precedent in the context of the present dispute so as to make sure that the precedent is relevant and that, despite its foreign provenance, it cannot be regarded as completely alien to the legal framework in relation to which it is being considered as authoritative. Conversely, any appeal to foreign precedents should be regarded as arbitrary and unjustified if the precedents used in the judicial justification of a ruling have not been specifically debated in the courtroom.

It emerges from the foregoing remarks that the dialectical approach we are defending, for one thing, locates our present engagement with precedents front and centre, and for another it makes the binding force of a foreign precedent by and large conditional on that precedent's substantive justification in the eyes of the prosecutor, the parties, and the judge in the current legal proceeding. To many, the latter conclusion flies in the face of the classic doctrine of precedent, which attaches formal, vis-à-vis substantive, authority to precedents in law. As a result, the dialectical approach may be interpreted as effectively denying the authoritative force of foreign precedents. However, this interpretation can only be defended if legal authority is conceived in accordance with what can be termed the 'deferential model' of authority - a model irreconcilable with the fundamental idea behind the dialectical approach. From a dialectical point of view, no authority can conclusively command deference, since all legitimate authority ultimately owes its binding force and directive power to the rationality of discursive processes. Therefore, in a framework based on dialectic, the authority associated with precedent in law can only be characterised as 'dialogic' authority, in contrast to deferential authority. Let us further expand on this point, which is fraught with theoretical implications.

An authority can be characterised as deferential insofar as it issues content-independent directives providing exclusionary reasons for action. ${ }^{3 \mathrm{I}}$ On this conception, an authoritative statement is considered

${ }^{31}$ This notion of authority is paradigmatically argued for in $\mathrm{J}$ Raz, The Authority of Law: Essays on Law and Morality (OUP I979), 3-33; J Raz, The Morality of Freedom (OUP ı986), 23-ı55; J Raz, 'Facing Up: A Reply' (ı989) 62 Southern California Law Review ı53-ı255, п179-120о; J Raz, Practical Reason and Norms (Hutchinson 1990), 4984; J Raz, Ethics in the Public Domain: Essays in the Morality of Law and Politics (Clarendon Press I994), I94-22I, and J Raz, 'The Problem of Authority: Revisiting 
binding, not by virtue of the soundness of its substantive rationale, but simply in virtue of its having been issued by a competent institution at some point in the past. When considered authoritative in this deferential sense, past decisions are claimed to affect later disputes even if those decisions turn out to be substantively incorrect or mistaken. Precedents so construed can thus be qualified as 'opaque' to their own rationale: their binding force is independent of their underlying justification. Now, that is the traditional doctrine of precedent, implied in which it is, then, a deferential notion of authority. To state it otherwise, precedents in law are traditionally found to be authoritative in the deferential sense just discussed.

This is not so from a dialectical perspective, which outright rejects the notion of deferential authority. In fact, the deferential model of authority is grounded in theoretical presuppositions that cannot be made compatible with the fundamental principles of discursive rationality. Deferential authority can be said to follow an exclusionary logic, for it instructs one to behave in a certain way and to disregard certain substantive reasons for acting otherwise. This exclusionary logic makes it so that, in the words of Joseph Raz, the statements issuing from an authority enjoy "a relative independence from the reasons which justify them" and can be regarded as "complete reasons in their own right" ${ }^{32}$ Quite the opposite is true of discursive rationality, which proceeds from an ideal of communicative exchange operating on a principle of openness to criticism. Discursive rationality gives expression to the idea of a dialogue, or discursive exchange, between parties making different claims. It thus frames and legitimises discussions in which each party is allowed to introduce any claim or argument whatsoever (so long as it is pertinent) and to rebut any claim or argument made by the counterparty. ${ }^{33}$ On this approach, then, every claim will be assessed on its own merits. Here we have an ideal of rationality where nothing escapes the reach of critical scrutiny, and so everything may be brought into the discussion and then also challenged. This means that from a dialectical perspective shaped by the principles of dialectical rationality, (legitimate) authority is not based on deference, since on the dialectical model certain questions

the Service Conception' (2005) 9o Minnesota Law Review ioo3.

${ }^{32} \mathrm{~J}$ Raz, Practical Reason and Norms (Hutchinson i99o), 79.

${ }^{33}$ This point is argued at length in $\mathrm{R}$ Alexy, A Theory of Legal Argumentation (Clarendon Press i989, or edn 1978), ı87-197. 
are not barred from consideration for the sole fact that a competent institution has decided that there should not be any further deliberation on a given rule, and so the rule is protected from additional scrutiny. On a dialectical approach, by contrast, authority is grounded in dialogue, understood as a form of communication where any claim needs to be subjected to collective scrutiny before it becomes the basis for a decision. ${ }^{34}$ So, on a dialectical theory, the kind of authority precedents can aspire to is not deferential, but dialogic.

Dialogic authority can be defined in the sense expounded in Cunliffe's and Reeve's seminal work as a kind of authority that only commands temporary power-delegation and conditional submission. ${ }^{35}$ What it means for one to be under an authority in the dialogic sense under

${ }^{34}$ The idea of discursive rationality, we submit, is best accounted by relying on the metaphor of a dialogue between parties making conflicting claims. This statement is justified by the fact that in our framework of thought discursive rationality refers to a set of standards emerging from the structure of exchanges between individuals who mutually recognise the counterparty as a partner having equal rights and dignity in a joint enterprise (practical deliberation). Related, one only complies with the requirements constitutive of discursive rationality insofar as, when putting forward her claims, she does not seek to impose her views on the counterparties or to merely persuade them, but rather she is concerned with consincing the counterparties of the soundness, or normative correctness, of her position. Accordingly, the notion of discursive rationality can hardly be described in terms of kinds of interpersonal conversations that follow a non-dialogic structure, such as, for instance, negotiations going on between parties bearing conflicting interests. For, whilst those concerned play an essential role in the proceedings governed by the standards of discursive rationality, in the theoretical model we are defending, controversies cannot be settled in any way the parties may like, or regard it to be in their own interest, as it is instead the case with negotiation-like processes. By contrast, the conduct of the parties involved in an exchange informed by the standards of discursive rationality is controlled by a set of principles that put constraints on the options available to those parties. Hence, discursive rationality shapes practical reasoning as an activity regulated by norms that are not settled by, or negotiated between, the concerned parties and so largely pre-exist the actual interactions between those parties. This dimension sets the processes governed by the principles of discursive rationality apart from the standard forms of bargaining and negotiation, which the parties are free to model as they go along on the basis of their own preferences. The metaphor of dialogue we rely on, in sum, is meant to emphasise the fact that discursive rationality is not reducible to the merely prudential kind of practical reason governing negotiation-like enterprises, or bargaining-like activities, which are ultimately intended to merely match the actual objectives and needs of the concerned parties.

${ }^{35}$ J Cunliffe and A Reeve, 'Dialogic Authority' (r999) i9 Oxford Journal of Legal Studies 453 . 
consideration is to be under certain practical constraints. Those subject to dialogic authority are not free to act on the basis of their best judgment about the case at hand: they understand that they may very well have to accept a course of conduct contrary to that judgment. However, this submission to dialogic authority does mean that one has to unconditionally suspend her capacity for practical judgment and independent action. Those subject to authority are rather dealing with a momentary and partial delegation of our practical prerogatives. By acknowledging an institution or practice as a dialogic authority, one accepts to defer to it in practical matters of public policy, while retaining the right to question those in authority if they should issue directives that may be argued to depart too much from what is substantively correct in accordance with the principles of dialectical rationality. ${ }^{36}$ So, dialogic authority is such that those in authority are empowered to govern, but on the understanding that that power can be revoked at any time. This means that, on the one hand, those in authority are always accountable for the rules they issue, but at the same time those subject to authority retain their independence even in those areas where they have delegated their power to act on their own best judgment, since that delegation is temporary and revocable, having been granted subject to a condition of accountability.

So, the claim that precedents are authoritative in a dialogic sense, rather than in a deferential one, means that while precedents do have a binding force, that force is neither absolute nor content-independent. Recourse to a precedent is justified only insofar as the conclusion it reaches and the reasons offered in support of that conclusion are found to be compelling by those who subsequently participate in settling legal disputes involving relevantly similar cases. Failing this condition, precedents cannot be legitimately used in legal adjudication, and so cannot be said to have a binding force.

It bears pointing out here that, on a dialectical approach, authoritative precedents come not with just any sort of reason, but with reinforced reasons that carry extra weight in supporting a judicial decision. Unlike an ordinary, or not reinforced, reason, which can only be judged on its

${ }^{36}$ As it is put in J Cunliffe and A Reeve, 'Dialogic Authority' (I999) I9 Oxford Journal of Legal Studies 453, 462, 'a movement from deferential authority to dialogic authority occurs when the authority-subject begins to insist on some elaboration of the reasons underlying the requirements or judgements of authority'. 
own merits, a reinforced reason gains justificatory force, on top of that inherent soundness, by virtue of its source. In other terms, if a reason or argument was put forward by an authoritative institution in keeping with an established method of reasoning, it will enjoy a prima facie plausibility, or presumption of correctness, that other reasons (those not so issued) cannot claim for themselves. However, the point here is that reinforced reasons, and the precedents in which they are contained, can be understood in two different ways depending on the view of authority in light of which they are considered.

From the standpoint of authority in a deferential sense, reinforced reasons are exclusionary (they bar competing reasons regardless of how compelling they may be); from the standpoint of authority of in a dialogic sense, their reinforced status does not rule out a priori the ability to invoke other substantive reasons. So, on a dialectical approach, as much as precedents may trump other reasons in light of which the case at hand could be decided, this 'reinforced' priority is not so entrenched as to exclude those other reasons altogether: these will always live in the background, from which they can always be pulled out, reintroduced, and brought to bear on the case at hand. That is because, as we have been discussing, precedents owe their binding force not just to their source (to the fact of their having been issued by a competent authority) but also, and importantly, to their underlying justification, and precedents that no longer reflect this second component - by virtue of their ruling out all justificatory reasons other than the ones adduced in the precedent itself, thereby forestalling any further reasoning - cannot be said to be binding.

In sum, on a dialectical approach, precedents and the justificatory reasons adduced in their support are distinct, but ultimately connected: although they form distinct classes, the separation is only temporary and limited, not absolute. This is so because, on this view, an authoritative precedent differs from a substantive justification by reason of its force. An authoritative precedent bears on the outcome of judicial deliberation not by barring substantive reasoning, but by competing with other practical reasons from a position of advantage (by virtue of its having a pedigree, or being 'reinforced'). Reasoning with precedent therefore involves a systematic bias: the reinforced reasons attached to precedents will generally outweigh, by virtue of their source, any other reasons that would otherwise apply. As a result, 
a precedent will as a matter of fact prevail on conflicting substantive reasons most of the time, though not always. For there may well be cases in which the additional strength built into an authoritative precedent will not enable it to trump or outweigh conflicting substantive reasons. In these cases it will be legitimate for courts to depart from precedent. Such a departure is possible only under special circumstances, however, meaning that it is a really strong argument that one will have to present in order to rebut a precedent. ${ }^{37}$ This means that when a court is confronted with a precedent, it is presumptively bound to follow it. However, this obligation is neither absolute nor ultimately content-independent, since it can be disobeyed when concurrent reasons supporting an alternative decision turn out, upon scrutiny, to be stronger than those sourced to a precedent. So, although precedents come with a stronger justificatory force, that force is nonetheless defeasible. ${ }^{38}$

Now, the reader may have noticed that in our account of the authority of precedents we have not distinguished domestic and foreign precedents. That is because, from a dialectical perspective, both kinds of precedents should be understood as authoritative statements in the dialogic sense. This position follows from the more general claim that we should do away with any rigid separation between what is inside a system of law and what is outside. From a dialectical perspective, legal systems can hardly be conceived as standalone or rigorously separated orders: the separation between different legal systems is at best partial and relative. Indeed, on a dialectical approach, law is conceived as a global phenomenon, an interconnected web of principles, policies, and provisions that may well have its boundaries, making for discontinuities and local differences, but not to such an extent as to result in a set of isolated units without any communication between them. Law so conceived is only contingently connected to its territory, since the legal domain is a common space inhabited by courts and litigants from different regions and traditions.

\footnotetext{
${ }^{37}$ On the defeasibility of authoritative directives, and the exceptional circumstances in which they may fail to exert their authority, see W Waluchow, 'Authority and the Practical Difference Thesis: A Defence of Inclusive Legal Positivism' (2000) 6 Legal Theory 45 .

${ }^{38}$ These points are expanded in S Perry, 'Judicial Obligation, Precedent and the Common Law' (1987) 7 Oxford Journal of Legal Studies 2r5 and S Perry, 'SecondOrder Reasons, Uncertainty and Legal Theory' (I989) 62 Southern California Law Review 913.
} 
This should not be taken to mean that local history, tradition, and culture have no role in shaping the law. Quite the contrary: it is a significant role that they play in that regard. But it is also true, as a matter of practice, that the line between national law and international law is constantly being blurred in adjudication. In light of that background, the idea that national legal systems are self-contained and mutually impenetrable spheres - an idea typically associated with the dominant view - turns out to be no more than an ideological claim sitting poorly with current practices in legal adjudication. Indeed, that idea fails to appreciate the interconnectedness of law in a world where economic, social, and political interactions cross national borders, and the fact that legal adjudication must adapt, for it is increasingly dealing with legal disputes which often reflect that reality, involving parties operating in a transnational context. So, just as the socioeconomic system is internationalising, so should legal deliberation and decisionmaking. In fact, this is precisely the trend, considering that adjudication is increasingly being shaped by principles shared on a global level.

The dialectical approach to reasoning with precedent must accordingly be understood as conceptually linked to an internationalist legal perspective. From such a perspective, the use of foreign precedents in domestic adjudication is seen as an example of the increasing internationalisation of law and as a paradigmatic way in which a legal system can affirm its membership in the international community through processes of adjudication. Accordingly, the rigorous distinction between domestic and foreign precedents can be argued to be artificial - grounded in ideology rather than in theory. In this context, a precedent should be conceived as a legal resource capable of shedding light on disputes beyond the domestic sphere. From the dialectical point of view, thus, when an issue debated in one jurisdiction crops up in another, those engaged in settling the more recent dispute should not be barred from borrowing legal arguments previously devised elsewhere. Because legal systems around the world often face similar problems, comparing and testing solutions found abroad is not only legitimate, but also rational. After all, past decisions may well make it possible to see the present controversy from a different angle and turn it into a tractable affair. With the ability to rely on precedents regardless of where they have been set, a constitutional 
court or an international tribunal can broaden its perspective by including new ideas, viewpoints, and opinions into the current legal proceeding. Since useful insights can be garnered from other legal systems, a system of law stands to lose by clinging to a practice of foreclosing possible avenues of deliberation, excluding potentially sound modes of reasoning and decision-making just because they are not the product of domestic judicial practices.

In the same spirit, it is essential, from a dialectical perspective, that foreign precedents should not merely be cited as window-dressing. In order for foreign precedents to be able to serve as valuable lessons in domestic adjudication, they need to be thoroughly discussed in the legal proceedings in the jurisdiction for which they are being considered as possible solutions: the legal experience developed elsewhere needs to be genuinely engaged with by the prosecutor, the parties, and the judge in their effort to find the best solution to the case at bar, for otherwise recourse to foreign precedent would turn into a mere academic exercise, which is not how legal reasoning and reasoning with precedent are conceived on the dialectical approach. In accordance to the latter, legal argumentation is conceived not as a monological enterprise, but as a form of collective deliberation; it is not something that can be achieved by a lone agent - typically the judge - on an isolated, almost heroic quest for the normatively correct settlement of any legal dispute. ${ }^{39}$ Even assuming that judges do have such skills, and even considering that they have the last word in the settlement of a legal dispute, its outcome will not have the backing of a full justification unless the claims made by the parties are debated in the context of an adversarial procedure that contributes to shaping the final judicial decision through a process of discursive exchange. Judges, in other words, should not be able to ignore the claims, reasons, arguments, interpretations, and narratives that prosecutor and parties introduce in the courtroom in making their case: in order for a judicial opinion to be legitimate, it must take into account the full spectrum of possibilities laid out by prosecutor and parties through a procedure that makes it possible for them to hear and challenge each other's

${ }^{39}$ The reference here is to Dworkin's law-as-integrity theory, which conceives legal adjudication as a practice shaped by Hercules, a mythical figure of judge entrusted with the solitary task of reconstructing the entire legal system as a coherent whole in deciding any dispute. This view is introduced in $\mathrm{R}$ Dworkin, Taking Rights Seriously (Duckworth 1977) and fully developed in $\mathrm{R}$ Dworkin, Law's Empire (Fontana i986). 
claims..$^{40}$

In conclusion, on a dialectical approach, which views reasoning in law as a structurally open process that can legitimately bring outside sources of adjudication into the legal proceeding, adversarial procedures and discussion are central to the process of legal reasoning. The only condition is that those sources come into the legal proceeding through a process of discussion. For it defeats the purpose of adjudication to introduce reasons and decisions into it uncritically, without the benefit of adversarial scrutiny through the participation of prosecutor and parties.

\section{Conclusion}

In this paper, we have set out to offer a qualified justification for a practice that has become widespread among courts in several jurisdictions across the world: that of settling domestic disputes by recourse to foreign precedents. To this end we blocked out a dialectical theory of legal reasoning as an activity structured by communicative exchanges between the parties in a courtroom and governed by general principles of discursive rationality. Legal reasoning, we argued, can thus be understood as an open-ended dialectical enterprise defined by two components, one of which is structural (the adversarial procedure) and the other substantive (the principles of rationality). What makes it open-ended is both the structure (that of a debate) and the substantive principles, since these are solid enough that they cannot be dismissed, so they have a role in shaping the discussion, and yet they are not so specific that they can fully determine its outcome. The gist of the argument, thus, was that this view of legal reasoning adequately captures the nature of authority in law and that of recourse to precedents (including foreign ones) in legal adjudication.

The theory we defended recognises both the context-sensitive nature of legal reasoning and its discursively rational character. On the one hand, we claimed that from a dialectical perspective, no deliberative activity carried out in legal proceedings is fully legitimate unless it is grounded in adversarial structures enabling all the parties affected by

40 This point is discussed at length in P Sommaggio, Contraddittorio, Giudizio, Mediazione (Franco Angeli 2012), I39-42. 
the judicial decision to discuss and scrutinise the arguments and narratives offered by the counterparties. This is a process through which not only the outcome, but also the structure of legal reasoning in adjudication cannot be predetermined. That is, a decisive factor in determining the structure and outcome of legal reasoning is given by the behaviour of the prosecutor, the parties, and the judge as they engage in debating competing reconstructions of the dispute and the applicable law. On the other hand, we argued that this particularistic element, inherent in the very idea of dialectic, is combined with another element, which is that all sound reasoning is governed by a number of general and abstract principles of discursive rationality. These principles act as regulative ideals internal to, and constitutive of, the very practice of arguing and discussing. They are, in other words, an essential condition of the possibility of legal reasoning. Importantly, this claim also is supported by our view of legal reasoning as a dialectical activity. Indeed, we noted that a dialectical approach to reasoning in law requires a prosecutor, the parties, and a judge to set up exchanges in such a way as to enable them to work through some dispute or disagreement. To this end they each need to be able to proffer, assess, and challenge a range of reasons and arguments that can be adduced in support of the claims they or the other side is making. This practice - that of deliberation, argument, and counterargument - rests on constitutive principles of its own that define the fundamental presuppositions failing which the practice would not be possible to begin with (if it is to come out as a deliberative practice rather than a conversational one in a broader sense). At least three such principles of discursive rationality can be named - those of non-contradiction, coherence, and universalisation and they are recognised as universally binding insofar as they are necessary, for, clearly, you cannot have a proper discussion with someone, or come to an agreement with them, if they insist on making contradictory claims and offering reasons which only they can accept or which only suit their own interests. A discussant may make a strategically successful move, but if the claims and arguments put forward in making that move turn out to be inconsistent or incoherent, or if they cannot be universalised, then the move places the discussant outside the argumentative realm, that of genuine reasoning. This means that no one who ignores the principles of consistency, coherence, and universalisation can have access to the realm of argumentation. The principles of discursive rationality should in this 
sense be considered necessary standards: they are valid independently of whether those engaged in argumentation explicitly recognise them, and so they act as preconditions for anyone wishing to argue intelligibly with anyone else. 